Names, Vol. 32, No. 2 (June 1984)

\title{
Manners Make Laws: Married Women's Names in the United States
}

\author{
UNA STANNARD
}

\begin{abstract}
$\mathrm{T}$ he fundamental facts about married women's names and the law are simple. After the eleventh century when surnames began to be used in England, it gradually became the custom for women to change their name to their husband's. They did so as a matter of choice, availing themselves of the right of English people to change their name at will. As Chief Justice Edward Coke said in 1628, though a person may have only one Christian name, "he may have divers surnames . . . at divers times," 1 the Chief Justice himself having a wife who did not use his surname. Even after it became well-nigh universal among English-speaking people for a woman to change her name to her husband's, England continued to recognize that the custom was not "compellable by law. It has no statutory authority or force."'2 American common law follows English common law in regard to names. Nevertheless, whenever an American woman chose not to follow custom, she was almost invariably told by bureaucrats, lawyers, and judges that her name, will-she nill-she, had automatically been changed by her marriage as a matter of law. Not until very recently has the American legal profession been able to face the facts of English common law.
\end{abstract}

\section{I: LUCY STONE}

The legal difficulties of Lucy Stone, probably the first nineteenthcentury American woman to keep her own name after marriage, ${ }^{3}$ were a forecast of the way the American legal profession was to handle the problem in the twentieth century.

In July 1856 , some fourteen months after her marriage to Henry B. Blackwell, Lucy Stone definitely decided to stop using her husband's name and call herself Stone again. She had consulted lawyers, all of whom assured her that taking a husband's name was only a custom, that no laws required her to change her name to her husband's. Among the 
lawyers she consulted was Salmon P. Chase, later to be Chief Justice of the Supreme Court.

Upon reverting to her own name, Lucy Stone immediately began to have legal difficulties. Rarely could she sign her own name to legal documents. Most of the time she was constrained to use the form, "Lucy Stone, wife of Henry Blackwell." Since "wife of" is the old-fashioned equivalent of Mrs., she was really being required to use two names - the one she insisted was her own and Mrs. Henry Blackwell, the name that legally counted. However, even that form would not satisfy the Massachusetts Board of Registrars. In 1879 a law was passed giving Massachusetts women the right to vote for members of the school committee. Overjoyed, Lucy Stone duly registered under that name. But the Board of Registrars erased her name from the rolls, informing her that she could not vote unless she used the name Blackwell. Stone insisted that the name she had used for over sixty years was her legal name and that no law compelled a wife to take her husband's name. She was even willing to use the form ' 'Lucy Stone, wife of Henry Blackwell,' but the Board of Registrars maintained that she could vote only if she signed her name Lucy Blackwell.

Stone considered fighting the Board's ruling, but she decided that the right to vote merely for members of the school committee was not worth the trouble and expense of a legal battle. ${ }^{4}$ As a consequence, she lost her vote, and worse. The Board of Registrars converted its decision in regard to Lucy Stone into the general ruling that "A married woman must vote bearing her husband's surname." 5 But that was not the only effect. Lucy Stone's attempt to defy custom may well have occasioned legal statements restrictive of women's name rights written shortly after 1879 . It must be remembered that Lucy Stone was famous; her troubles with the Board of Registrars were discussed in newspapers in several states. Be that as it may, in the next edition of their legal texts on marriage, two Boston attorneys laid down nominal law. Joel P. Bishop's Commentaries on the Law of Marriage and Divorce, first published in 1852, went through five editions without mentioning names, but in the 1881 edition Bishop added section 704a: "The rule of law and custom is familiar, that marriage confers on the woman the husband's surname." Similarly, James Schouler in his Treatise on the Law of Domestic Relations did not discuss names until the 1882 edition when he included section 40: "Marriage at our law does not change the man's name, but it confers his surname upon the woman."

Moreover, in an 1881 case, Chapman v. Phoenix National Bank, a 
New York Judge, Robert A. Earl, made the following statement about married women's names:

For several centuries, by the common law among all English-speaking people, a woman, upon her marriage, takes her husband's surname. That becomes her legal name, and she ceases to be known by her maiden name. By that name she must sue and be sued, make and take grants and execute all legal documents. Her maiden surname is absolutely lost, and she ceases to be known thereby. ${ }^{6}$

Read out of context, one would think the judge was laying down the law to another Lucy Stone, but the case had nothing to do with such a woman. Since Judge Earl's words were to become the ones most quoted in the legal annals of married women's names, it is important to know what the case was actually about. It concerned the attempt of a Southerner, Verina S. Chapman, to get back her shares of stock in a New York bank that had been confiscated during the Civil War. The judge made the above statement because the confiscation notice had been issued in the name Moore, the maiden name under which Mrs. Chapman had bought the stock when she was single, the judge feeling the notice should have been issued in her married name. But since Mrs. Chapman had not informed the bank of her marriage and change of name, the government officials who issued the confiscation notice had no way of knowing her new name. But this fact Judge Earl did not discuss. The real misnomer issue in the case was that an entirely wrong person had been named in the notice, one "Ver. S. Moore," who was alleged to be, among other things, a member of the Confederate Congress. Moreover, despite the judge's strong views on married women's names, the case was decided in Mrs. Chapman's favor not because her maiden name had appeared in the confiscation notice but because the bank, as the trustee of her stock, had surrendered it without making any effort on her behalf.

The case could have been decided without any discussion of married women's names. One therefore cannot help wondering if Judge Earl, having read in the papers about Lucy Stone's troubles with the Board of Registrars, decided to use the case as a vehicle for voicing his opinion on the subject. For it should be understood that his statement is what in law is called a judicial dictum; a statement on a legal point other than the one a judge is deciding in the case. Since the legal point is not being reviewed or examined, the judge's words are not supposed to be treated as if they were a considered judicial decision. In practice, however, they often are, and Judge Earl's statement on married women's names was later to be treated like a commandment handed down from Mt. Sinai, and this despite the fact, not only that it was a dictum, but that it revealed total ignorance of the common law of names. 
It was not that the facts were unknown in America. Another New York judge in an 1859 case had discoursed learnedly on the origin of surnames and a person's common law right to do what he wished with his name. ${ }^{7}$ Judge Earl could also have easily looked up an 1823 English case in which a judge decided that " a married woman may legally bear a different name from her husband."'8 Moreover, a few years after Chapman v. Phoenix National Bank, The American and English Encyclopedia of Law (188796) was to state correctly what the common law was in regard to names: "By custom, the wife is called by the husband's name; but whether marriage shall work any change at all is, after all, a mere matter of choice, and either may take the other's name, or they may join their names together.", 9

That that was the common law of names was, interestingly enough, demonstrated in England in 1879, the same year Lucy Stone had her troubles with the Massachusetts Board of Registrars. Florence Fenwick Miller, a member of the London School Board, had married Frederick A. Ford and with his consent and by previous arrangement she kept her own name. In 1879 she was re-elected to the School Board, but her election was objected to on the grounds that her legal name was really Ford. Fenwick Miller, unlike Lucy Stone, proceeded to fight, preparing her case so well it never got to court, for the officers of the Crown were advised they could not win since the common law allowed any person, even a married woman, to use any name he or she chose. ${ }^{10}$

But that was England. In America Lucy Stone's experience was to be typical. Her difficulties with the Board of Registrars and the effect her non-conformity had on the legal profession were a forecast of the future. What happened to her was to happen again and again to non-conformist women in the twentieth century.

\section{II: THE LUCY STONE LEAGUE}

In November 1918 when New York women voted for the first time, the married women who wanted to vote in their own name ran into trouble. According to Ruth Hale, "registrations were refused and a few women even arrested for attempting to vote in their own names.", 11

It may surprise some to learn that in 1918 there were women who were keeping their own name after marriage. But every feminist movement has produced women who decide that marriage should not deprive them of their identity. In the nineteeth century a few isolated rebels followed Lucy Stone's example, but in the 1910s a new feminist movement arose that produced hundreds of women who felt as Fola La Follette did in 1914 when she gave the first speech wholly devoted to the subject - that a 
woman should no more change her name in marriage than a man. ${ }^{12}$ It was these women who had trouble registering to vote and who were having so many other bureaucratic and legal difficulties that in 1921, one of them, Ruth Hale, founded the Lucy Stone League. Hale had had several attorneys research the law, and since they discovered no laws that required a wife to use her husband's name, she decided that the purpose of the League need only be educational: to inform the public and bureaucratic functionaries that a wife had a legal right to use her own name.

During its first five years the League had great success. Since many of its members were journalists working on New York newspapers, its goals and activities got considerable press coverage. In addition, the League managed to get various business and government officials to acknowledge a wife's own name, among them the New York election board, which changed its ruling and agreed that a married woman who continued to use her maiden name could vote in that name. Indeed, the climate of legal opinion was such that the Attorneys General of Maryland and Michigan in 1921 and 1923 issued opinions that a woman registered under her maiden name was not required to reregister after marriage. ${ }^{13}$ The League even succeeded in getting the State department to rule that married women who did not change their name could be issued passports in their own name. In commenting on that ruling, an English law journal felt that "the right of married women to use their maiden surnames as their legal names has been recognized" 'by the United States Government. ${ }^{14}$ By the end of 1925 the League felt with some justification that it had accomplished its goal.

But just as in 1879 Lucy Stone's attempt to vote in her own name brought about an election regulation compelling married women to vote in their husband's name and probably the inclusion in a case and legal texts of pronouncements that a married woman's only legal surname was her husband's, so the success of the Lucy Stone League led to a series of rulings, Annotations, case decisions, Attorney General Opinions, and interpretations of laws that eventually made it difficult and often impossible for a married woman to use her own name. As early as 1919, in response to the growing number of women who were choosing to reman Miss Themselves after marriage, the first legal article on married women's names had been published, and "Proper Designation of Married Women in Legal Proceedings"' unequivocally stated that "The law confers upon a wife the surname of her husband."'15 But it was not until 1924 at the height of the Lucy Stone League's success that the legal backlash really began.

In 1924 Comptroller General J. R. McCarl, reacting to a married 
woman who wanted to use her own name, ruled that married women employed by the Federal government must sign their husband's name to the payroll, for that was their only legal name. McCarl argued that most states had abrogated the common law of names because they had laws on their books that presumed "the name of the woman is changed to that of her husband at marriage." These were divorce laws that gave courts the power to restore the maiden name of a wife after divorce, McCarl asserting that a married woman "must have lost her maiden name, otherwise it could not be restored." McCarl further said that legal reference works and case law both established that a wife's legal name was her husband's. $\mathrm{He}$ quoted from Schouler's Domestic Relations that marriage confers the husband's "surname upon the woman," and cited seven cases in which he said that rule of law was sustained. ${ }^{16}$

The next year, in 1925, American Law Reports published an Annotation on "Correct name of married woman" in which its author, George Van Ingen, cited many more cases which he also felt sustained that rule of law, even though in not one case was the right of a married woman to retain her name before the court. The cases were cited merely because they contained a judge's assertion or assumption that a married woman's surname had to be her husband's. Among the cases cited was Chapman $v$. Phoenix National Bank, which was cited three times. ${ }^{17}$

The following year, in 1926, the Chapman case was again cited when a Massachusetts judge decided that in registering an automobile a married woman must use her husband's surname. ${ }^{18}$ Following the lead of Comptroller General McCarl, the judge interpreted a Massachusetts divorce law (permitting a judge to restore a married woman's maiden name after divorce) as a marriage law mandating a name change for married women. As a result of this case a note was appended to that law (Ch.208, 23 General Laws of Massachusetts) declaring that "In view of this section, as matter of law, after her marriage, a married woman's legal name becomes that of her husband.' Massachusetts thus became the first state then in the Union to put in its code a statement that a woman's legal name after marriage was her husband's. Moreover, the case soon became well known in legal circles, for in 1927 American Law Reports reprinted it with an Annotation on names and the registration of automobiles. ${ }^{19}$

It was by such means - converting divorce laws into virtual marriage laws and citing cases that contained merely judicial dicta - that the legal profession began to establish that a married woman's only legal surname was her husband's.

But what, one may ask, was the Lucy Stone League doing to combat 
these legal restrictions? In 1924 the League, together with the National Woman's Party, had prepared to fight McCarl's ruling, but the woman involved left the government service, the case was dropped, and the ruling stayed on the books. After 1925 the League became less and less active, many Lucy Stoners being influenced by the cult of wife and motherhood that was then taking place. As Dorothy Thompson wrote in her diary in 1927 , the real woman was the one who was "swallowed up by a man" and thus transmuted into something "better than herself." 20 Former militant Lucy Stoners began using their husbands' names. Esther Sayles Root, one of the first women to get a passport in her own name, by 1934 was calling herself Mrs. Franklin P. Adams. ${ }^{21}$

Nevertheless, a great many Lucy Stoners did continue using their own name, and although the Lucy Stone League was eventually forgotten, there continued to be women who decided when they married not to change their name. One such was Antonia Rago, a Chicago attorney, who married in 1944 and was forthwith informed by the Chicago Board of Election Commissioners that in order to continue to be a legally registered voter, she must reregister under the name of her husband. Not to do so, said the Board, was a violation of an Illinois election law that required any voter who "changes his or her name by marriage or otherwise" to reregister.

Rago protested that the law did not apply in her case because she had not changed her name when she married, that her only name was the one she had been known by from birth in her community. A Superior Court agreed with her and ordered the Board to restore her name to the files. The Election Board, however, appealed that decision and in November 1945 it was overturned, Judge Friend of the Appellate Court maintaining that the Illinois election law "expressly recognizes a change of name by marriage," that Rago had no choice in the matter because according to "the long-established custom, policy and rule of the common law among English-speaking peoples,' as maintained in Chapman v. Phoenix $\mathrm{Na}$ tional Bank, a woman's name upon marriage becomes "as a matter of law" her husband's surname. ${ }^{22}$

But English common law had not changed. Indeed, in the same year Judge Friend was telling Antonia Rago that under English common law she was compelled to change her name to her husband's, a judge in England was saying, "There is, so far as I know, nothing to compel a married woman to use her husband's surname."'23

But the correct facts of English common law were somehow ignored, and as a result of the Illinois case other states interpreted similar voter reregistration laws as laws mandating a name change for married women. 
For example, in 1952 the Oregon Attorney General, when refusing to permit a married woman to get a business license in her maiden name, said that Oregon's reregistration law furnished "substantial proof that the legislature regarded marriage as changing a wife's name." 24

Although no state passed a law requiring women to change their name at marriage, ${ }^{25}$ other means were used to force women to conform. A few states, like Maryland and Maine, passed watchdog laws, ones that required the marriage bureau to report the names of women issued marriage licenses to the registrar of voters, who then cancelled their registration, informing them that in order to vote they had to reregister in their husband's name. Other states added to their State Digests (summaries of a state's important cases) actual statements, like "A married woman's name consists, in law, of her own Christian name and her husband's surname, marriage conferring on her the surname of the husband.' This statement appeared in the Nebraska Digest, but when one checks the 1957 case that apparently decided that issue, one discovers that the judge only decided that married women in signing a petition had to use their own Christian names, and not their husbands'. ${ }^{26}$ Interestingly enough, the other states that added similar statements to their Digests (Florida, Minnesota, Alabama), also cite cases in which a decision was made only about a married woman's first name.

It was by such dubious means - summarizing a decision about a married woman's first name as if it were also a decision about her surname, twisting divorce, automobile, and voter registration laws into marriage laws mandating a name change, and by a studied ignorance of what English common law actually was ${ }^{27}$ that the legal profession managed to amass a great weight of judicial precedents, all apparently maintaining that:

At marriage the wife takes the husband's surname and the surname of the husband, so taken at marriage, becomes her legal name. Her maiden surname is absolutely lost, and she ceases to be known thereby. ${ }^{28}$

Thus begins the section on "Name of Married Woman" in the Corpus Juris Secundum (a compendium of case decisions). ${ }^{29}$ The volume containing this section was published in 1966, and to see how much material had been accumulating one need only compare it with the comparable section in the first edition. In the Corpus Juris married women's surnames were discussed in volume 30 (published in 1923) in the section under "Husband and Wife" and consisted of one sentence supported by three case citations. ${ }^{30}$ In the Corpus Juris Secundum "Name of Married Woman" is a separate section three paragraphs long and supported by three 
columns of citations. And in not one of the cases cited did a judge decide that a wife could have a name different from her husband's. Since one of the aims of the Corpus Juris is to report "conflicting and inconsistent decisions" so that trends in the law can be recognized, ${ }^{31}$ whoever consulted this section would conclude that no cases had occurred in which a judge held that a married woman's legal name need not be her husband's.

But the fact was that two such cases had occurred, both in Ohio. Ohio had a law requiring those who changed their name "by marriage or otherwise" 'to reregister to vote. In 1941 Gertrude A. Bucher, an attorney, filed a petition to run for the City Commissioner of Dayton, but her petition was refused on the grounds that since her marriage she had not reregistered to vote in her new name. Bucher maintained that since she and her husband had agreed before the marriage that she would retain her own name, that her name had not changed. The Ohio Court of Common Pleas agreed with her. In a lengthy opinion, much of it concerned with the origin of surnames and the long established common law right to change one's name at will, the judge pointed out, among other things, that the Ohio election law did not mandate a name change for women, that no such law was in the General Code of Ohio, and that when a wife did change her name to her husband's she was exerting her common law right to change her name at will. ${ }^{32}$

Twenty years later, in 1961, there was a similar case. Another attorney, Blanche Krupansky, filed to run for Judge of the Municipal Court, but the Board of Elections refused to print her name on the ballot on the grounds that her legal surname was Vargo, the surname of her husband, in which name, said the Board, she had also failed to reregister to vote. Blanche Krupansky, like Gertrude Bucher, appealed that decision and won her case, the court pointing out that "It is only by custom, in Englishspeaking countries, that a woman, upon marriage, adopts the surname of her husband," and that although Ohio follows this custom, "there exists no law compelling it.' '33

It is extraordinary that these Ohio cases, heard in higher courts and printed in State Reports, were not cited in the annual Pocket Parts of the Corpus Juris or in the Corpus Juris Secundum. George Balluff, the Managing Editor, told me in 1973 that their omission was a simple oversight, but the cases were known: the editors of the volume published in 1965, the year before the one containing the section on married women's names, cited the cases under Elections 48. Moreover, the section on married women's names had many cross-references to motor vehicle laws, divorce laws, and even to Elections $113 \mathrm{~b}$, but no cross-reference to Elections 48. Nor were the two Ohio cases cited in American Jurispru- 
dence (a standard legal reference work), nor in the various updatings of American Law Reports' 1925 Annotation on "Correct name of married woman."'

The omission of the Ohio cases from legal reference works meant that decisions upholding a married woman's right to use her own name would be hard to ferret out. Certainly, Antonia Rago, who was an attorney, did not in 1945 discover the 1941 Ohio case or she would have cited it since her situation and that of Gertrude Bucher were almost identical. It is hard to believe that the omission of the Ohio cases from all legal reference works was a simple oversight, for their omission was in line with the tendency of the law since the mid 1920s when, as a reaction against the successful work of the Lucy Stone League, bureaucrats, legal researchers, attorneys, and judges made use of a variety of dubious means to try to establish that a married woman must as a matter of law take her husband's surname.

\section{III: Common Law Revived}

That the law compelled a wife to change her name to her husband's was the general legal opinion in the late 1960s when a new wave of feminism began and women again began to feel the injustice of having to give up their names at marriage. Whereas in the 1920s the Lucy Stone League influenced a few hundred women to keep their own name, from the late 1960 s to the early 1970 s thousands of women from all over the country, women associated with no organization and many of whom denied they were feminists, spontaneously decided they would not take their husbands' names or would divest themselves of a husband's name they had previously taken.

Among these women was Mary E. Stuart who, when she married Samuel H. Austell in Virginia in 1971, decided to keep her own name as " a symbol of her independence." 34 But since the law then held that a married woman's surname was her husband's, how could Mary Stuart put her belief in nominal independence into practice? No one, of course, could stop her from using her own name socially, but how could she register to vote or get a driver's license in her own name? And in fact, Mary Stuart, like many other women, ran into the legal stone wall.

A few months after her marriage, she moved to Maryland where in 1972 she registered to vote, disclosing to the registrar that she was married but used her own name for all purposes. Two weeks later the Board of Supervisors notified her that under Maryland law "'a woman's legal surname becomes that of her husband upon marriage," that she must 
therefore reregister under her husband's name or her registration would be cancelled. She was further informed by the State Administration of Election Laws that it was "a settled principle of common law that marriage automatically operates to change the wife's surname to that of her husband," and that she could vote in her own name only if she had her name changed by court order. Stuart challenged that decision, but a Circuit Court decided against her, the judge maintaining that the wife's use of her husband's name was "based on the common law of England, which has been duly adopted as the law of this State." 35 Meanwhile, the State Motor Vehicle Administration, having learned of Stuart's troubles in the newspapers, searched its files and discovered it had issued her a driver's license in the name Stuart. The Administration forthwith informed her she had violated the law and that unless she changed her name by court order or got a new license in her husband's name, her driver's license would be revoked.

It is not surprising that administrators and judges believed as they did. Even feminist attorneys then thought so. Leo Kanowitz, when researching married women's names for a book on women and the law concluded that "in the United States, the change in a woman's name upon marriage . . . appears to be generally required by law." 36 The authors of an article on the Equal Rights Amendment in the Yale Law Journal also believed that the merger of a woman's legal identity into her husband's was "firmly entrenched in statutory and case law,", 37 and Marija M. Hughes in an article on married women's names in the 1971 Hastings Law Review also concluded that "it is almost a universal rule in this country that upon marriage, as a matter of law, a wife's surname becomes that of her husband. "38 More important, in September 1971 a Federal Court decided that because Alabama had "adopted the common law rule that upon marriage the wife by operation of law takes the husband's surname," Alabama had the right to require married women to use their husband's name on their driver's license, ${ }^{39}$ a decision that in March 1972 was affirmed, but without briefs and without hearing arguments, by the United States Supreme Court.

One might have thought, then, that the cause was lost, and that Mary Stuart and the many other women who wanted to keep their own name after marriage could only do so if they had their name changed from their husband's by court order. But Mary Stuart decided to appeal the decision of the lower court and the lawyers who took her case thought the subject of sufficient importance so that the basic legal research was finally done. The 1941 and 1961 Ohio cases that had upheld a wife's right to continue using her own name were discovered. Whereas Kanowitz in his Women 
and the Law had described Chapman $v$. Phoenix National Bank as a case in which a judge denied a woman's request to use her own name after marriage,${ }^{40}$ the case was finally read and found to have nothing to do with such a woman, the judge's statement being merely a dictum. More important, that judge's oft-repeated opinion that "by the common law among all English-speaking people, a woman upon her marriage, takes her husband's surname"' was at long last found to be false, a fact that any lawyer or judge could easily have discovered if he had merely consulted such a basic reference work as Halsbury's Laws of England. ${ }^{41}$ Why judges and lawyers had not done so will probably forever remain hidden in the annals of legal prejudice. Be that as it may, correct knowledge of the common law was finally ascertained.

Using this knowledge, the Ohio precedents, and also invoking the equal protection clause of the Fourteenth Amendment, briefs were prepared in behalf of Mary Stuart's right to vote in her own name, and in October 1972 the Maryland Court of Appeals (the state's highest court) upheld a married woman's right to use her own name, the judge stressing the common law right to use the name of one's choice: "Under the common law of Maryland, as derived from the common law of England, Mary Emily Stuart's surname . . . has not been changed by operation of law to that of Austell solely by reason of her marriage . . . [Although] long-standing custom and tradition has resulted in the vast majority of married women adopting their husbands' surnames as their own - the mere fact of marriage does not, as a matter of law, operate to establish the custom and tradition of the majority as a rule of law binding upon all." 42

As a result of this case, the legal profession reversed itself. Whereas judges used to maintain that voter or automobile reregistration laws requiring persons who changed their names "by marriage or otherwise" mandated a name change for married women, they now held that such laws applied only if the woman had in fact changed her name. In state after state Attorneys General began issuing opinions upholding a wife's right under the common law to continue using her own name. Starting in December 1973 the Passport Office again began permitting married women to be issued passports in their own name, if they presented proof they had continued to use their own name. From 1972 to the present almost forty states, either by decisions in higher courts, legislation, ${ }^{43}$ or Attorney General Opinions have acknowledged that when a woman takes her husband's name, she does so under the old common law right to use the name of one's choice, that married women, therefore, cannot be compelled to use their husband's name for any purpose. Even to get a divorce. In the 1920s when Lucy Stoners got divorced, they had to petition the 
courts under their husband's name, but in January 1976 a California Appeals Court held that a woman who used her own name during marriage was entitled to sue for divorce in that name. ${ }^{44}$

It is important to note that women won the right to a name of their own on common law, not equal rights, grounds. Indeed, when regulations requiring women to use their husband's name were challenged on equal rights grounds, the cases were lost. The 1971 Alabama case denying a wife the right to have a driver's license in her own name, ${ }^{45}$ was argued on equal rights grounds. And in 1976 when Sylvia Scott Whitlow argued that the Kentucky regulation requiring married women to have drivers' licenses in their husbands' names violated her civil rights under the equal protection clause of the Fourteenth Amendment, she too lost her case. Interestingly enough, the United States Appeals Court said that state courts should determine if under the common law of Kentucky a woman's legal name was in fact changed to her husband's at marriage, which suggests that if Whitlow's case had been argued on common law grounds at the state level, she would, like most other women, have won the right to use her own name. ${ }^{46}$

Although a few states, like Alabama, still maintain that upon marriage a woman's name as a matter of law is changed to her husband's, most states now recognize that under the common law a woman's change of name at marriage is a matter of choice. But does such recognition necessarily mean that American women have at long last won the seemingly minor right to a name of their own? Samuel Johnson observed that "As manners make laws, manners likewise repeal them," 47 and should another cult of wife and motherhood supervene, as it did in the late twenties and thirties, American married women might again be in danger of losing their name rights. However, so many case decisions upholding a wife's right to her own name are now on the books that it seems to me that states would have to pass statutes compelling married women to change their name to their husband's.

The fundamentalists and conservatists among us would like such laws passed, for they believe that if family members do not all have the same name, the structure of the family will be seriously undermined. But those who hold this view always fail to ask why, in a society in which $99 \%$ of wives do take their husband's name, the annual rate of divorce rose by $80 \%$ between 1960 and the early 1970s and continues to rise?

For despite the new wave of feminism, most women still continue to change their name at marriage. The women who do not are a tiny percentage. Although among them are some prominent women (like Jane Byrne, the former mayor of Chicago, and Maureen Reagan, the president's 
daughter), most women do not want to keep their own name after marriage. Not until it becomes the custom for all wives to keep their own name will more than a small percentage of women do so. In America these non-conformists can only hope they will continue to be tolerated. England, with its greater acceptance of eccentricity, managed to tolerate Lucy Stoners without violating its common law. But American judges, to force a few wives to conform to custom, turned common law inside out. De Tocqueville observed that Americans were more emotionally bound to conformism than Europeans, but perhaps we are changing. At least Judge Stapleton, in deciding in 1974 that married women in Connecticut could vote in their own name, said that although "the vast majority of women will continue to follow the social custom of our times and adopt their husbands' surnames,' law should not mandate custom, should respect those who "hear a different drummer." 48

\section{Notes}

'Commentaries on Littleton, $3 \mathrm{a}(\mathrm{m})$.

${ }^{2} \mathrm{M}$. Turner-Samuels, The Law of Married Women (London: Thames Bank, 1972), p. 345.

${ }^{3}$ Mary Walker may have preceded her. For a discussion of the priorities, see Una Stannard, Mrs Man (San Francisco: Germainbooks, 1977), pp. 132-133.

${ }^{4}$ For a full account of Lucy Stone's legal difficulties, see Stannard, op. cit., pp. 93-110.

${ }^{5}$ Reprinted in The Woman's Journal, 10 (August 2, 1879), 247.

${ }^{6}$ Chapman v. Phoenix National Bank, 85 N.Y. Rep. 437, 449 (1881).

7Petition of Snook, 2 Hilton's Reports 566 (1859).

${ }^{8}$ The King v. The Inhabitants of St. Faith's, 3 Dowling \& Rylands Reports 348 (1823).

${ }^{9}$ (Northport, Long Island, New York: E. Thompson), 9, p. 813.

${ }^{10}$ See Stannard, p. 131.

"The First Five Years of the Lucy Stone League (New York: The Lucy Stone League, n.d.[1925?]), p. 19

${ }^{12}$ Reported in The New York Times, Feb. 20, 1914, p. 18.

${ }^{13}$ Annual Report and Official Opinions of the Attorney General of Maryland, 1921, pp. 188-189;

Biennial Report of the Attorney General, Michigan, 1923-24, p. 138.

${ }^{14}$ The Law Journal, 60 (Nov. 21, 1925), 941.

${ }^{15}$ Virginia Law Register, 4 (Feb. 1919), 721.

${ }^{16}$ Decisions of the Comptroller General, 4, July-Sept. 1924 (A-4147), pp. 165-167.

1735 American Law Reports 413.

${ }^{18}$ Bacon v. Boston Elevated Railway, 256 Mass. Rep. 30 (1926).

1947 American Law Reports 1103.

${ }^{20}$ Quoted in Vincent Sheean, Dorothy and Red (Boston: Houghton Mifflin, 1963), pp. 33-34.

${ }^{21}$ See Stannard, p. 224

${ }^{22}$ People ex rel. Rago v. Lipsky, 327 Ill. App. Rep. 63 (1945).

${ }^{23}$ In re Fry, 1 Chancery Division 348 (1945).

${ }^{24}$ Biennial Report and Opinions of Attorney General of the State of Oregon, 1950-1952, pp. 375-377.

${ }^{25}$ Hawaii, when it became a state in 1959 , already had such a statute (Ch. $\left.574-1\right)$ in its books. Originally passed in 1860 , it required Hawaiian women, who did not used to take their husbands' names, to conform to Western custom. 
${ }^{26}$ Kelle v. Crab Orchard Fire District, 164 Neb. 593 (1957).

${ }^{27}$ For a full discussion of the various means used, see Stannard, pp. 239-261.

${ }^{28}$ Note that this last sentence is an actual quote from Judge Earl's dictum in Chapman v. Phoenix National Bank.

${ }^{29} 65$ Corpus Juris Secundum 4.

3030 Corpus Juris 511.

${ }^{31}$ See Preface, 1 Corpus Juris vii.

${ }^{32}$ State ex rel. Bucher v. Brower, 21 Ohio Opinions 208 (1941).

${ }^{33}$ State ex rel. Krupa v. Green, 19 Ohio Opinions 2d 341 (1961).

${ }^{34}$ Washington Post, June 16, 1972, p. C1.

${ }^{35}$ Stuart's legal troubles are summarized in Stuart v. Board of Elections, 266 Md. 440, 443 (1972).

${ }^{36}$ Women and the Law (Albuquerque: Univ. of New Mexico Press, 1969), p. 42.

${ }^{37}$ Brown, Emerson, Falk \& Freedman, "The Equal Rights Amendment: A Constitutional Basis for Equal Rights for Women," Yale L.J. 80:940, 1971.

3823 (November 1971), 235.

${ }^{39}$ Forbush v. Wallace, 341 Fed. Supp. 217 (M.D. Ala. 1971).

${ }^{40}$ Loc. cit.

41 "When a woman on her marriage assumes, as she usually does in England, the surname of her husband . . . it may be said that she acquires a new name by repute. The change of name is in fact, rather than in law, a consequence of the marriage." 19 Halsbury's Laws of England 829 (3d ed. 1957).

${ }^{42}$ Stuart v. Board of Elections, 266 Md. Rep. 440 (1972).

${ }^{43}$ For example, California passed a law declaratory of existing law, that is, of a person's common law right to change his name, and six states (Georgia, Hawaii, Iowa, Massachusetts, Minnesota, Oregon) passed laws requiring couples at the time of marriage to declare what name he/she will use after marriage, laws that the Attorney General of Iowa said did not prevent a married person in his state from later changing his/her name by common law, that is, without a civil procedure.

${ }^{44}$ Weathers v. Superior Court of Los Angeles, 126 Calif. Rep. 547 (1976). Since then women in other states have also successfully sued for the right to be divorced in their own names. See Simmons v. O’Brien, 272 N.W.2d 273, a 1978 Nebraska case, and Malone v. Sullivan, 605 P.2d 447, a 1980 Arizona case.

${ }^{45}$ Forbush v. Wallace, supra, note 39.

${ }^{46}$ Whitlow v. Hodges, 539 F.2d 582 (6th Cir. 1976).

${ }^{47}$ Boswell's Life of Johnson, in a letter dated Feb. 9, 1776.

${ }^{48}$ Custer v. Bonaides, 30 Conn. Sup. Ct. 387, 390 (1974). 